\title{
Generation and Validation of Crack Growth Resistance Curve from DCB Specimens: An Experimental Study
}

\author{
V. Alfred Franklin ${ }^{\mathrm{a}, 1}$ and T. Christopher \\ ${ }^{a}$ Sardar Raja College of Engineering, Alangulam, Tirunelveli, India \\ ${ }^{\mathrm{b}}$ Government College of Engineering, Tirunelveli, India \\ ${ }^{1}$ frank_vin@yahoo.com
}

УДК 539.4

\section{Построение и обоснование кривой трещиностойкости при испытании образцов в виде двухконсольной балки: экспериментальное исследование}

\author{
В. Альфред Франклина \\ а Технический колледж им. Сардара Раджи, Алангулам, Тирунвели, Индия \\ ${ }^{\sigma}$ Государственный технический колледж, Тирунвели, Индия
}

Исследуются вязкость разрушения и межслойная разрушающая нагрузка для образиов в виде двухконсольной балки из стекла/эпоксидной смоль, которые наносились тремя разньли слоями. Для построения кривой трещиностойкости (R-кривая) с помощью представленной модели необходимо знать историю приложенной нагрузки-перемещения и распространение трешины. На основе построенной $R$-кривой определена разрушающцая нагрузка на границе раздела слоев для образцов. Полученное значение разрушающей нагрузки хорошо соответствует экспериментальному значению.

Ключевые слова: образцы в виде двухконсольной балки, $R$-кривая, стекло/ эпоксидная смола, авиационная конструкция, расслоение.

\section{Notation}

a $\quad-$ crack length

$B \quad-$ width of the DCB specimen

$C \quad-$ compliance of the specimen

DCB - double cantilever beam

$E \quad-$ longitudinal tensile modulus

$G_{\mathrm{I} R} \quad-$ strain energy release rate (SERR)

$G_{\text {Ic }} \quad-$ fracture toughness or critical strain energy release rate

$2 h \quad-$ specimen thickness

$K \quad-$ rotational spring stiffness at the crack tip

$P \quad-$ applied load on both sides of the specimen

$\delta \quad-$ crack mouth opening displacement

$\Pi \quad-$ potential energy

(C) V. ALFRED FRANKLIN, T. CHRISTOPHER, 2013 
Introduction. Laminated composite plates and shells are increasingly being used in aircraft and aerospace structures because of their high strength to weight ratio, stiffness to weight ratio, thrust to weight ratio and design versatility. Laminated composites are highly customizable because the required state of stress level can be achieved by adopting different fiber orientations and/or stacking sequence. The fracture processes in composite materials are complex and is strongly dependent upon stacking sequence, fiber orientation and constitutive relations. Failure may occur due to fiber-breakage, debonding of fibers, delamination, formation of matrix micro-cracks and other micro-failure modes. Many researchers investigated whether the linear elastic fracture mechanics (LEFM) established for metals is applicable to fiber reinforced composites or not. It is observed that when the crack surface is smooth and straight and the crack propagates with selfsimilarity, the problem can be analyzed by LEFM; otherwise the result may not be correct. Therefore theories and criteria of linear elastic fracture mechanics must be suitably modified for composite structures. The failure mechanisms of composite structures is different from that of isotropic materials. These laminated structures have high resistance to crack propagation when they are subjected to tensile load along the fiber direction because the matrix and reinforcement jointly act to form a barrier to the crack propagation. Crack propagation in laminated composites is often not collinear but is characterized by the mixed mode [1].

Glass fiber composites were first used during World War II, which was about 20 years before carbon and boron fiber composites were used in aircraft structures. The earliest composites are made of E-glass fabric and polyester resin, and these were used in few niche components not subject to high loads such as fuselagelifting surface attachments or wings and empennage tips. At the time, the aircraft industry was reluctant to use glass fiber composites more widely because of the low stiffness of glass-fibers and poor strength and toughness of polyester resins, particularly at elevated temperatures. The development of stronger, tougher and more durable resins, such as epoxies lead to the increased use of E-glass laminates in some aircraft components viz., the entire airframe, wings and fuselage of modern gliders. In 1960s, the development of S2 glass, which has greater stiffness and strength than E-glass, allowed a greater variety of aircraft structures and components to be made. S-glass composites are often used as the face skins to ultra-light sandwich honeycomb panels and typical applications in commercial aircraft are wing-fuselage fairings, rudder and elevator surfaces and the leading and trailing edges of wing panels. Glass/epoxy honeycomb sandwich panels are also used in a variety of components on modern military aircraft, such as the fixed trailing edge on the B2 bomber. Another common use of E-glass composites is in radomes on commercial and fighter aircraft, in bay and wing mounted radomes on supersonic aircraft and missiles, and in large radar domes on Airborne Early Warning and Control (AEW\&C) military aircraft. This is because of the excellent transparency of glass to radar signals. Glass/epoxy is widely used in helicopter components, such as in the spars to the main and tail rotor blades, fuselage body panels and flooring [2].

The composite materials exhibit superior properties only along the fiber direction; hence the delamination of composite structures results in a significant loss of the strength and stiffness. As a result of this damage mechanism, the 


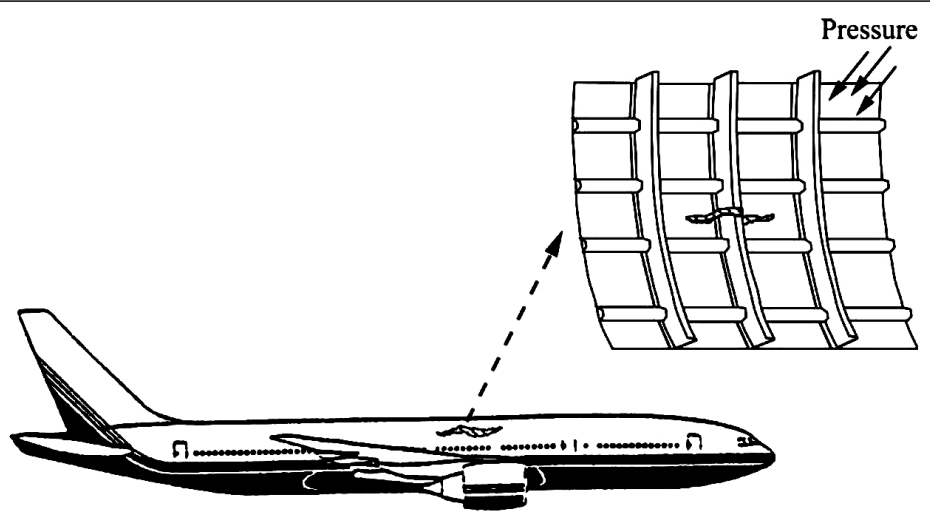

Fig. 1. Fuselage panel with discrete source damage [8].

fracture characterization of composites structures acquires special relevancy [3]. Publications by Boeing [4,5] reveal that the residual strength prediction of composite structures with discrete source damage (Fig. 1) is the area in which more research is needed.

The crack growth resistance curve was used to predict the ultimate strength of a damaged pressurized fuselage panel and was tested by Boeing [5].

Shokrieh et al. [6] proved that the $R$-curve can be used as a material property by selecting a certain specimen size for the DCB specimen in the range of $8.5<a_{0} / h<19$. Two unidirectional laminates of stacking sequence $\left[0^{\circ}\right]_{18}(B=25$ $\mathrm{mm}, 2 h=3.28 \mathrm{~mm})$ and $\left[0^{\circ}\right]_{24}(B=25 \mathrm{~mm}, 2 h=4.1 \mathrm{~mm})$ with different initial crack lengths are used for their study. But, Suo et al. [7] argued that the $R$-curve is not a material property since it depends on the specimen size. They recommended that $R$-curves can be used as an experimental probe to study localized damage response such as polymer craze and interface separation. Publication by NASA [8] proved that the $R$-curve method has the potential to be a practical engineering method for predicting the residual strength of damaged fuselage panels. The dependence of $R$-curves on the geometry of DCB specimens for unidirectional carbon/epoxy composite laminates and the peculiarities of $R$-curve obtained on traditional DCB specimens loaded by wedge forces and calculations to predict the resistance to crack propagation in specimens of different thickness was investigated by Tamuzs et al. [9].

The aim of the present study is to construct the crack growth resistance curves for glass/epoxy laminates of different stacking sequences and to predict the interface strength of composite laminates under monotonic loading.

1. Data Reduction. Usually the energy release rate in a DCB specimen is defined as

$$
G=\frac{\partial \Pi}{B \partial a}
$$

The generalised Irwin-Kies equation for SERR is given by

$$
G=\frac{P^{2}}{2 B} \frac{\partial C}{\partial a} .
$$


Considering root rotation, the compliance, $C$, is given by [10]

$$
C=\frac{\delta}{P}=\frac{2}{3} \frac{a^{3}}{E I}+\frac{2}{K} a^{2}
$$

Eliminating $K$ in Eq.(3), the fracture toughness can be evaluated from the fracture data as [11]

$$
G_{\mathrm{I} c}=\frac{P^{2} a^{2}}{3 B E I}+\frac{P \delta}{B a} .
$$

2. Experimental Work. The double cantilever beam (DCB) test is the most commonly used delamination test used for interlaminar fracture characterization under mode I loading and has been standardized by the ASTM [12]. The specimens used for the present study consist of different three lay-ups viz., unidirectional $\left[0^{\circ}\right]_{6}$, angle ply $\left[ \pm 45^{\circ}\right]_{3}$, and cross ply $\left[0^{\circ} / 90^{\circ}\right]_{3}$ laminates made of E-glass/epoxy. The reinforcing phase used is unidirectional glass fiber of $750 \mathrm{~g} / \mathrm{m}^{2}$. The matrix phase is epoxy resin LY 556 with hardener HY951 in the ratio of 10:1 to promote or control the curing action and also to control the degree of hardness of the cured film. The initial crack was made by introducing a thin teflon film of thickness $13 \mu \mathrm{m}$ during stacking procedure. Initially the upper and lower mould surfaces are cleaned using acetone to remove the dirt present. Once the dirt is being removed, wax is applied on both the surfaces. Mylar sheets were used to get better surface finish and ease in releasing the plate. The laminates contain six laminas to have the Teflon insert at the centre. The laminates were prepared by hand lay-up process. The excess resin present is squeezed by using rollers. The laminate is allowed to cure in the mould for about $24 \mathrm{~h}$ in room temperature and then post cured. As per ASTM standards the optimum length of the DCB specimen should be at least $125 \mathrm{~mm}$, the width of the specimen should be around 20 to $25 \mathrm{~mm}$ and the thickness can be between $3-5 \mathrm{~mm}$. The dimension of test specimen used here is $130 \times 25 \times 2 \mathrm{~h} \mathrm{~mm}$, exact width of specimen was obtained by using water jet cutting. The specimen surfaces are scrubbed with sand paper and are cleaned thoroughly with acetone to remove dirt. For better bonding, the base of aluminium piano hinge is also scratched with file and is cleaned with acetone. A thin layer of araldite adhesive is used to fix the piano hinge to the specimen. Care should be taken that the araldite applied doesn't cover the sides of teflon insert. Piano hinge is meant for applying load and to avoid moment at the loading point so that the load is always perpendicular to the face of specimen.

2.1. Experimental Setup. The specimens were tested [11] on Instron 3367 universal testing machine equipped with a $30 \mathrm{kN}$ load cell at room temperature. They were subjected to a wedge loading under displacement control. The cross head speed was set at $1 \mathrm{~mm} / \mathrm{min}$ to ensure steady crack propagation and ease of recording. The load-displacement $(P-\delta)$ history was recorded by the machine. Markings were made on the specimen on both sides starting from the end of the insert as per ASTM standards. First five markings are made in an interval of $1 \mathrm{~mm}$ and the following four markings are made in an interval of $5 \mathrm{~mm}$. A magnifying lens or a travelling microscope was used to track the crack propagation. The crack 
growth from the starter insert was determined by careful inspection of the specimen edge by magnification lens and by observation of $P-\delta$ curve.

3. Generation of Crack Growth Resistance Curves (R-Curves). Future lightweight composite transport aircraft will be designed to sustain discrete source damage (see Fig. 1) caused by uncontained engine failure. Poe et al. [13] used an energy balance approach called the $R$-curve method is being used for residual strength predictions of composite specimen under tensile load. Bui et al. [14] argue that two values of strain energy release rates must be considered in interlaminar fracture characterization: $G_{\text {Ic-init }}$ characterising delamination onset and $G_{\text {Ic-prop }}$ related to delamination steady-state growth. They assert that $G_{\mathrm{I} c}$ can be considered equal to the energy release rate recorded during delamination growth. However, they support that for a more realistic approach to the analysis of delamination, both values should be considered in the characterization of the $R$-curve effects.

Jacobsen et al. [15] modelled the $R$-curves of mode I intralaminar crack growth in composites using measured bridging laws. They confirmed that better accuracy is achieved if a nonlinear law is used instead of a linear one. They observed that under large-scale bridging the $R$-curve is not a material property. Moreover it was concluded that under this condition the linear elastic fracture mechanics approach overestimates the steady state crack growth resistance. They also argue that in this case, $J$-integral approach must be performed for accurate predictions.

Ozdil et al. [16] conducted an experimental study on glass/polyester quasiunidirectional and angle-ply laminate DCB specimens of lay-up sequences $\left[0^{\circ}\right]_{6}$, $\left[ \pm 30^{\circ}\right]_{5}$, and $\left[ \pm 45^{\circ}\right]_{5}$ with mid-plane delamination. They conclude that the initiation toughness decreases with increase in off-axis angles in angle ply laminates. Due to large-scale plasticity LEFM is not strictly applicable to the $\left[ \pm 45^{\circ}\right]_{5}$ specimens and hence nonlinear fracture mechanics based methods are to be considered. Polaha et al. [17] performed tests on DCB specimens made of graphite/epoxy laminates with ply interface angles $0^{\circ} / 0^{\circ}, 5^{\circ} / 15^{\circ}, \pm 15^{\circ}, 30^{\circ} / 30^{\circ}$, $\pm 30^{\circ}$. They found that the initiation and propagation toughness decreases with increase in lay-up angles. Laksimi et al. [18] studied the behavior of multidirectional glass/epoxy composite laminate under mode-I loading. To minimize coupling effects, the stacking sequence selected for their study was $\left[ \pm 0^{\circ}{ }_{2 s}\right]_{S}$ with $\theta=15^{\circ}, 30^{\circ}, 45^{\circ}$, and $60^{\circ}$. From their experiments, it is noticed that the orientation of angle, $\theta$ has no influence on $G_{\mathrm{I} c}$ and that the $G_{\mathrm{I} c}$ values are almost identical except $60^{\circ}$. For $\theta \geq 45^{\circ}$, the transverse crack (bifurcation) was observed by the authors. Because of rotation of the specimen due to the bifurcation, the crack propagates under a mixed mode produced by a shear stress.

It is generally reported that $G_{\mathrm{I} c}$ values at initiation, and especially at propagation, are higher than those of $\left[0^{\circ}\right]_{n}$ laminates. The main feature seems to be that, after relatively small interlaminar propagation, the crack jumps to a neighboring interface. In studies involving specimens with initial cracks in $+45^{\circ} /-45^{\circ}$ interfaces, the intralaminar damage and the extensive fiber bridging behind the crack tip were responsible for a pronounced increase of $G_{\text {Ic }}[16,19]$. Robinson et al. [20] observed that the quantity of fiber bridging significantly varies from specimen to specimen in $+45^{\circ} /-45^{\circ}$ interface. One of the specimens with $+45^{\circ} /-45^{\circ}$ interface exhibited extensive fiber bridging, gives a maximum $G_{\mathrm{Ic}}$ of 
$1.3 \mathrm{~kJ} / \mathrm{m}^{2}$ and another specimen exhibited much less fiber bridging gives a maximum $G_{\text {Ic }}$ of $0.6 \mathrm{~kJ} / \mathrm{m}^{2}$. Ramkumar et al. [21], studied the mode-I fracture using DCB specimens of two sequences $\left[0^{\circ}{ }_{24}\right]$ and $\left[0^{\circ}{ }_{2} / \pm 45^{\circ} / 0^{\circ}\right]_{S}$, made of carbon/epoxy (T300/5208) material. They found that the energy release rates of two specimen as 102.6 and $100 \mathrm{~J} / \mathrm{m}^{2}$, respectively and found they are closer. Laksimi et al. [22] argued that the strain energy release rates for the initiation cracks and the delamination growth, $G_{\mathrm{I} c-\text { init }}$ and $G_{\mathrm{I} \text { - prop }}$, respectively are higher for $\left[0^{\circ} / 90^{\circ}\right]$ or $\left[90^{\circ} / 90^{\circ}\right]$ interface layers than $\left[0^{\circ} / 0^{\circ}\right]$ layers. They argued that the presence of the $90^{\circ}$ plies in the propagation plane increases the delamination resistance. Morais et al. [23] clearly proved that $G_{\mathrm{I} c}$ values of $\left[0^{\circ} / 90^{\circ}\right]_{12}$ specimens were higher than those of $\left[0^{\circ}\right]_{24}$ ones and no fibre bridging was observed in the $\left[0^{\circ} / 90^{\circ}\right]_{12}$ specimens.

The $R$-curve method requires two steps to predict the residual strength of a damaged composite panel. The first step is to generate an "allowable-like" $R$-curve using energy release rates derived from tests of DCB specimens. The second step is to compute the energy release rates (generation of $G$-curve) of the specimen and to compare these values to the $R$-curve for the prediction of interface strength. Experiments were performed to obtain energy release rates for the DCB specimens subjected to wedge loads. Energy release rate vs. crack growth increment curves ( $G$-curves) for various loads are plotted. Since the $R$-curve is an allowable curve, the cracks cannot grow beyond the $R$-curve. The intersection of each $G$-curve and $R$-curve determines the crack growth increment for a corresponding load. In the present study, $R$-curve is generated using power law of the form $G_{I R}=G_{0}+$ $+A(\Delta a)^{m}$.

In the present work, the crack growth resistance curve of $\left[0^{\circ}\right]_{6}$ glass/epoxy DCB specimen was generated from the test data (Fig. 2a) and is given in the form $G_{\mathrm{I} R}=410+2828(\Delta a)^{0.3}$. Note that in Fig. $2 \mathrm{~b}$, the $G$-curve of the unidirectional $\mathrm{DCB}$ specimen at $123 \mathrm{~N}$ is tangent to the $R$-curve. Therefore, the present analysis predicts a large damage growth around $123 \mathrm{~N}$ and this value is very closer to the test result. For $\left[ \pm 45^{\circ}\right]_{3}$ glass/epoxy DCB specimens, the $R$-curve was generated from the test data (Fig. 3a) in the form $G_{\mathrm{I} R}=469+537(\Delta a)^{0.3}$. From the $R$-curve (Fig. 3b), the failure load obtained is $71.5 \mathrm{~N}$ for the laminate, which is lower than both the unidirectional and cross-ply laminates. For $\left[0^{\circ} / 90^{\circ}\right]_{3}$ lay-up, mathematically the $R$-curve (Fig. 4a) is given by $G_{\mathrm{I} R}=578+579(\Delta a)^{0.27}$. The $G$-curve (Fig. 4b) of $175 \mathrm{~N}$ is tangent to the $R$-curve (at a small crack growth increment of $1 \mathrm{~mm}$ ) and is the interface failure load of this specimen. From this present study it has been observed that the initiation toughness of $\left[0^{\circ} / 90^{\circ}\right]_{3}$ specimen is higher than $\left[0^{\circ}\right]_{6}$ and $\left[ \pm 45^{\circ}\right]_{3}$ specimens. From previous studies it is observed that the delamination growth in composites can occur too rapidly over a fairly small range of load and hence, $G_{\mathrm{I} c}$ needs to be considered in damage tolerance analysis [24].

4. Results and Discussions. Fracture analysis has been carried out on the double cantilever beam specimens made of glass/epoxy of three different lay-ups. The rotational stiffness of the support at the crack tip of the DCB specimen $K$ is determined by substituting the initially recorded fracture data (viz. load $P$, 


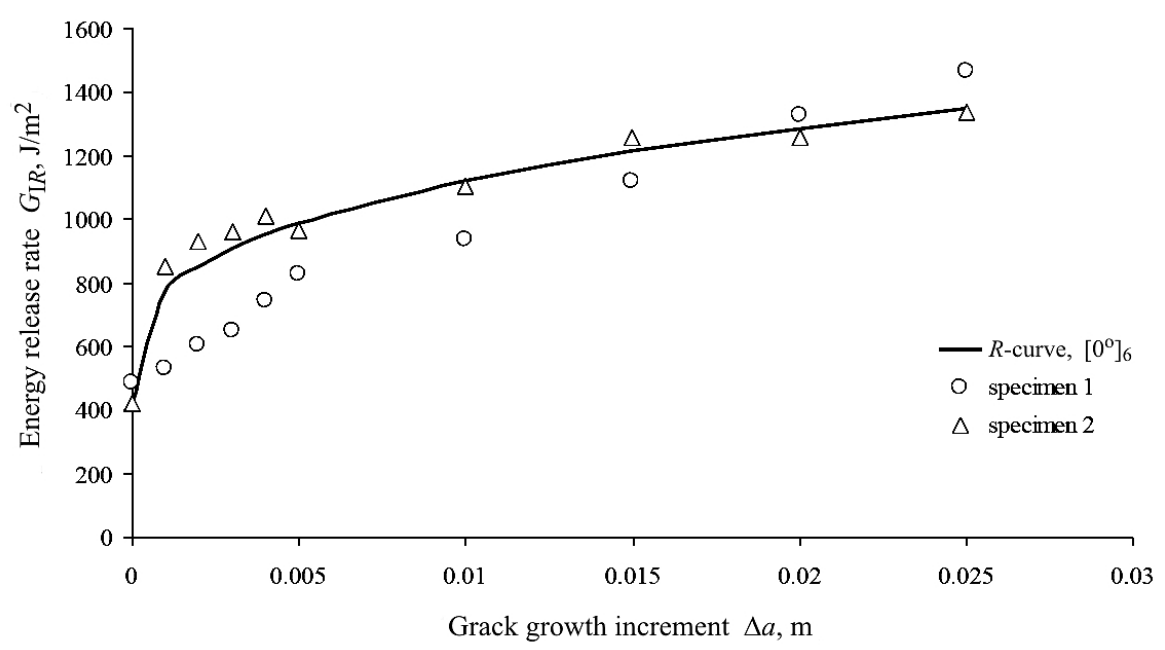

a

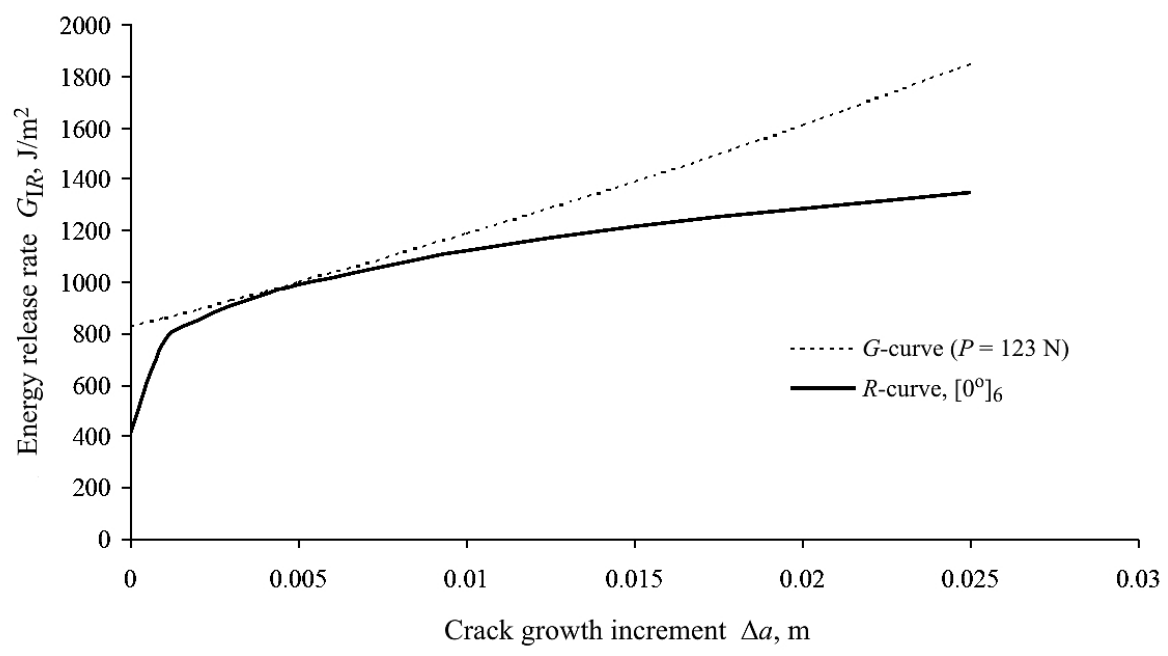

b

Fig. 2. $R$-curve of $\left[0^{\circ}\right]_{6}$ glass/epoxy DCB specimen from test data (a) and inter-laminar failure load from $R$-curve of $\left[0^{\circ}\right]_{6}$ DCB specimen (b).

displacement $\delta$, and crack size $a$ ) from the loading/unloading curves, and the Young modulus $E$ of the material. If the stiffness is very large, all the methods give almost closer results and hence the effect of $K$ may not be significant in the particular case [11]. The experimentally recorded $P-\delta$ history of DCB test specimens with crack were used to derive energy release rates. DCB specimens of three different lay-ups viz., $\left[0^{\circ}\right]_{6},\left[ \pm 45^{\circ}\right]_{3}$, and $\left[0^{\circ} / 90^{\circ}\right]_{3}$, with mid-plane delamination were used to measure energy release rates for the construction of the $R$-curve. The $G_{I R}$ vs. $\Delta a$ curve was generated for each specimen. Energy release rates for the DCB specimen under various wedge loads, a range of crack growth increments were computed and the results were used to construct $G$-curves of various loads. The $G$-curves of the DCB specimens were compared with the $R$-curve to determine the interface strength of the DCB specimen made of 


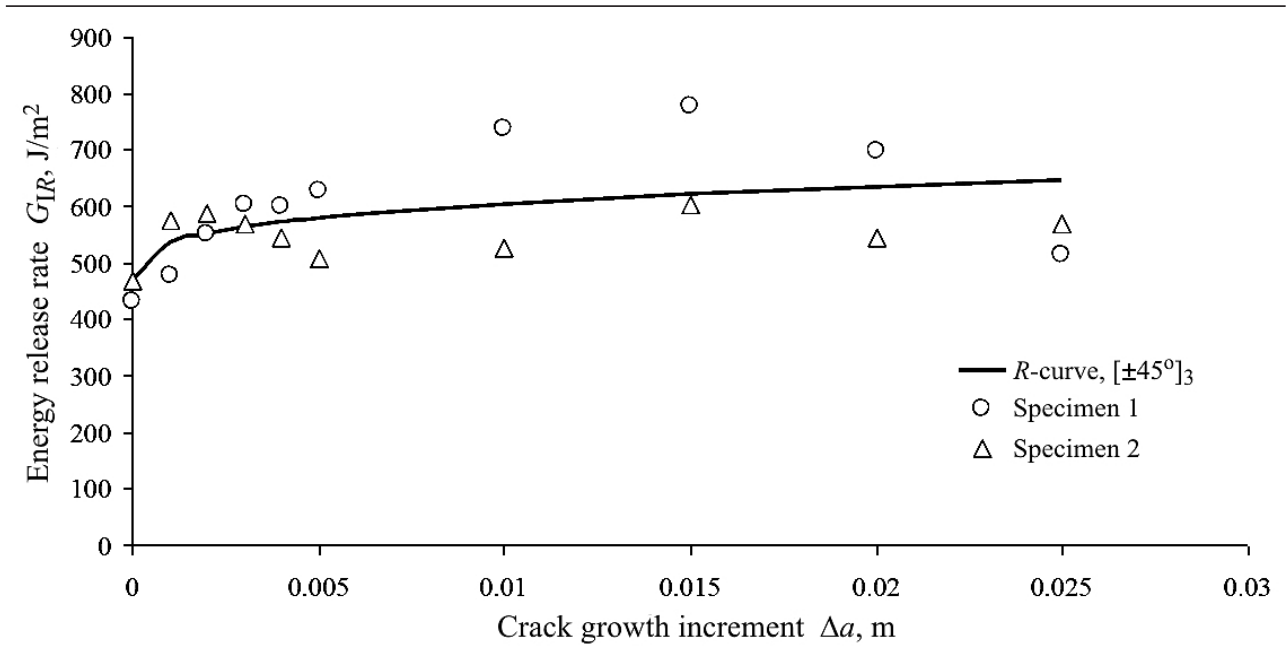

a

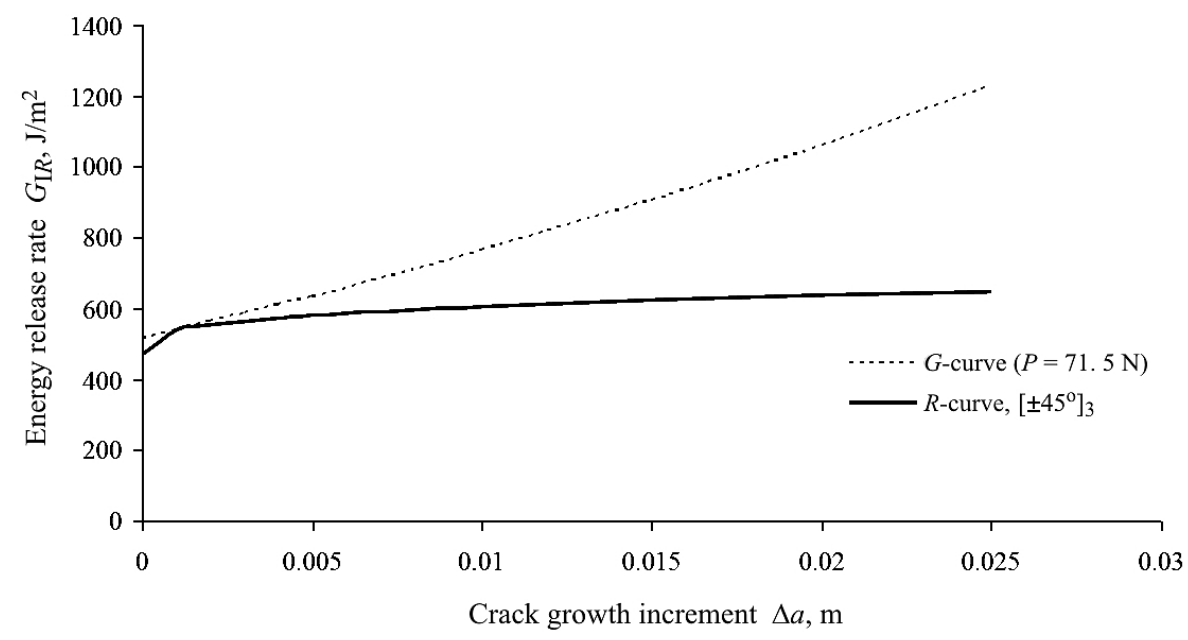

b

Fig. 3. $R$-curve of $\left[ \pm 45^{\circ}\right]_{3}$ glass/epoxy DCB specimen from test data (a) and inter-laminar failure load from $R$-curve of $\left[ \pm 45^{\circ}\right]_{3}$ DCB specimen (b).

glass/epoxy laminates. For a particular load $P$, the $G$-curve is tangent to the $R$-curve and at this load the catastrophic failure occurs, which is the interface failure load of the particular specimen. From Table 1 it is found that the correlation between the $R$-curve failure load predictions and the experimental results of present work is very good. This correlation suggests that the $R$-curve method has the potential for predicting the interface strength of composite laminates of different stacking sequence with delamination/damage.

The compliance variation with crack growth increment of DCB specimens of different lay-ups made of glass/epoxy is shown in Fig. 5. From Fig. 6, it has been observed that the initiation toughness of $\left[0^{\circ} / 90^{\circ}\right]_{3}$ specimen is higher than $\left[0^{\circ}\right]_{6}$ and $\left[ \pm 45^{\circ}\right]_{3}$ specimens which agrees with other publications and the propagation toughness of $\left[0^{\circ} / 90^{\circ}\right]_{3}$ laminate is less than that of unidirectional laminate which 


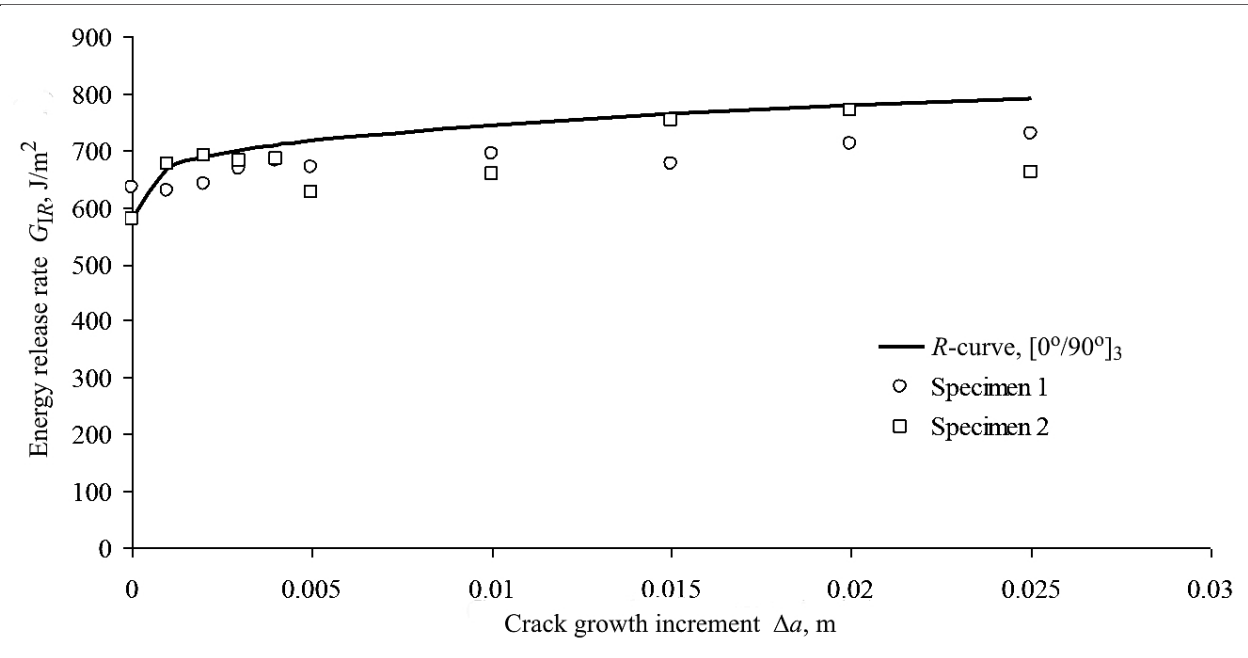

a

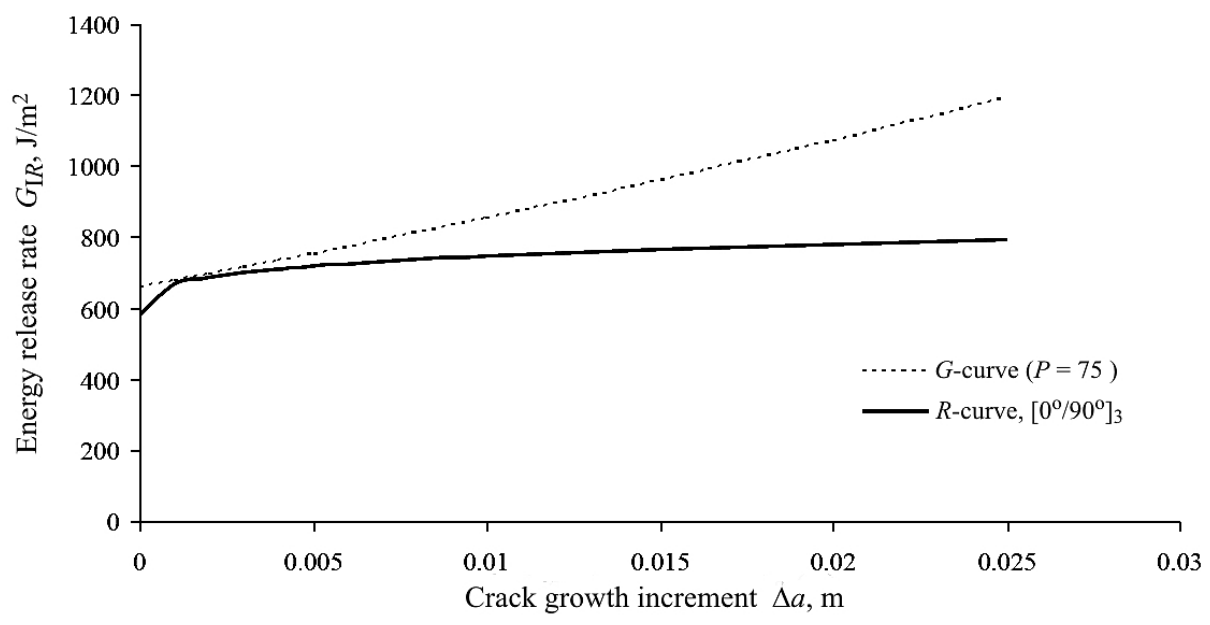

b

Fig. 4. $R$-curve of $\left[0^{\circ} / 90^{\circ}\right]_{3}$ glass/epoxy DCB specimen from test data (a) and inter-laminar failure load from $R$-curve of $\left[0^{\circ} / 90^{\circ}\right]_{3}$ DCB specimen (b).

conflicts with many of the publications $[24,25]$. The reason is that the $\left[0^{\circ}\right]_{6}$ laminate exhibited more fiber bridging during propagation than other two lay-ups. Fiber bridging causes a large, $G_{I c}$ value which overestimates the real mode I fracture toughness [25]. Also it is observed that the failure of cross ply laminate occurs at a smaller crack growth increment of $1 \mathrm{~mm}$; this may be due to the lack of fiber bridging and transverse matrix cracking of $90^{\circ}$ ply.

Delaminations that form in multi-ply laminated composite structures occur between plies of dissimilar orientation, fiber bridging does not occur. Hence, fiber bridging is considered to be an artifact of the DCB test on unidirectional materials. Therefore, the generic significance of $G_{\text {Ic }}$ propagation values calculated beyond the end of the implanted insert is questionable, and an initiation value of $G_{I c}$ measured from the implanted insert is preferred [12]. Since the lower bound of $G_{\text {Ic }}$ occurs in the absence of a fiber-bridged zone, one can conclude that $G_{\text {Ic }}$, increases 
Generation and Validation of Crack Growth Resistance Curve ...

$\mathrm{T}$ a b 1 e 1

Inter-Laminar Failure Load of E-Glass/Epoxy DCB Specimens of Different Lay-Ups

\begin{tabular}{|c|c|c|c|c|c||}
\hline \multirow{2}{*}{ Lay-up } & \multicolumn{3}{|c|}{ Energy release rate $G_{\mathrm{Ic}}, \mathrm{J} / \mathrm{m}^{2}$} & \multicolumn{2}{|c|}{ Interlaminar failure load $P, \mathrm{~N}$} \\
\cline { 2 - 6 } & Eq. (4) $[11]$ & $R$-curve & Experimental & $R$-curve & $\begin{array}{c}\text { Relative error } \\
(\%)\end{array}$ \\
\hline$\left[0^{\circ}\right]_{6}$ & $2 h=5.86 \mathrm{~mm}, a_{0}=43 \mathrm{~mm}, B=25 \mathrm{~mm}, L=130 \mathrm{~mm}, E=36 \mathrm{GPa}$ \\
\cline { 2 - 6 } & 1075 & 987.0 & 118.1 & 123.0 & 3.98 \\
\hline$\left[ \pm 45^{\circ}\right]_{3}$ & $2 h=6.36 \mathrm{~mm}, a_{0}=46 \mathrm{~mm}, B=25 \mathrm{~mm}, L=130 \mathrm{~mm}, E=12.9 \mathrm{GPa}$ \\
\cline { 2 - 6 } & 543 & 536.6 & 68.2 & 71.5 & 4.61 \\
\hline$\left[0^{\circ} / 90^{\circ}\right]_{3}$ & \multicolumn{2}{|c|}{$2 h=6.16 \mathrm{~mm}, a_{0}=47 \mathrm{~mm}, B=25 \mathrm{~mm}, L=130 \mathrm{~mm}$} \\
\cline { 2 - 6 } & 724 & 667.7 & 72.6 & 75.0 & 3.20 \\
\hline
\end{tabular}

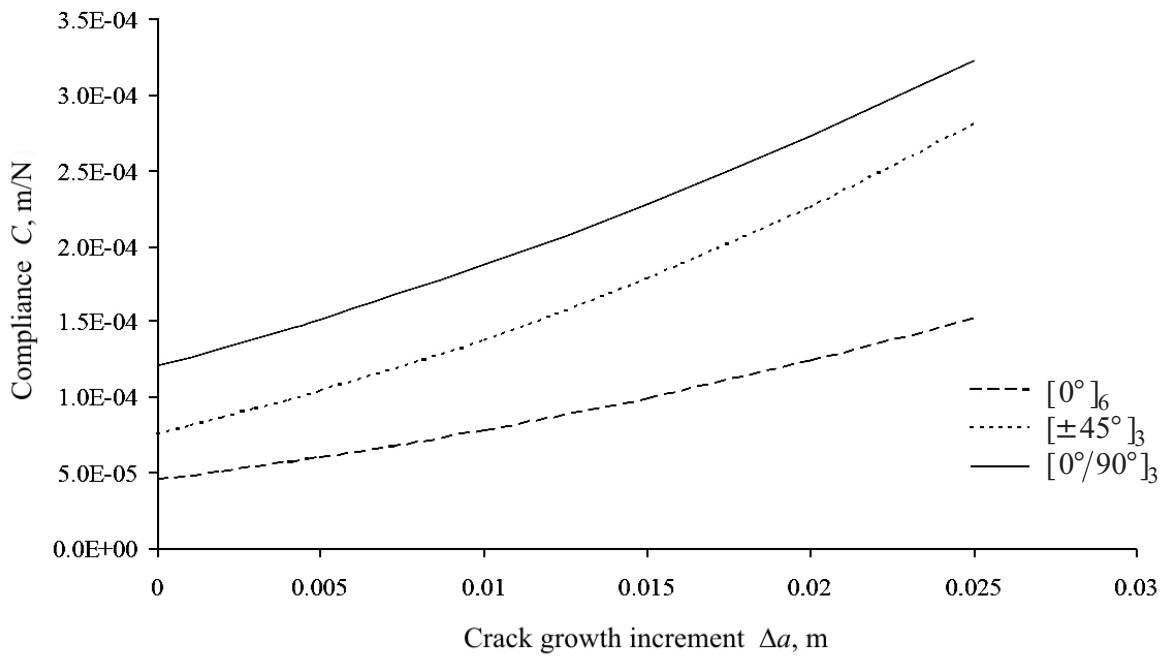

Fig. 5. Compliance variation with crack growth increment of DCB specimens of different lay-ups made of glass/epoxy (present study).

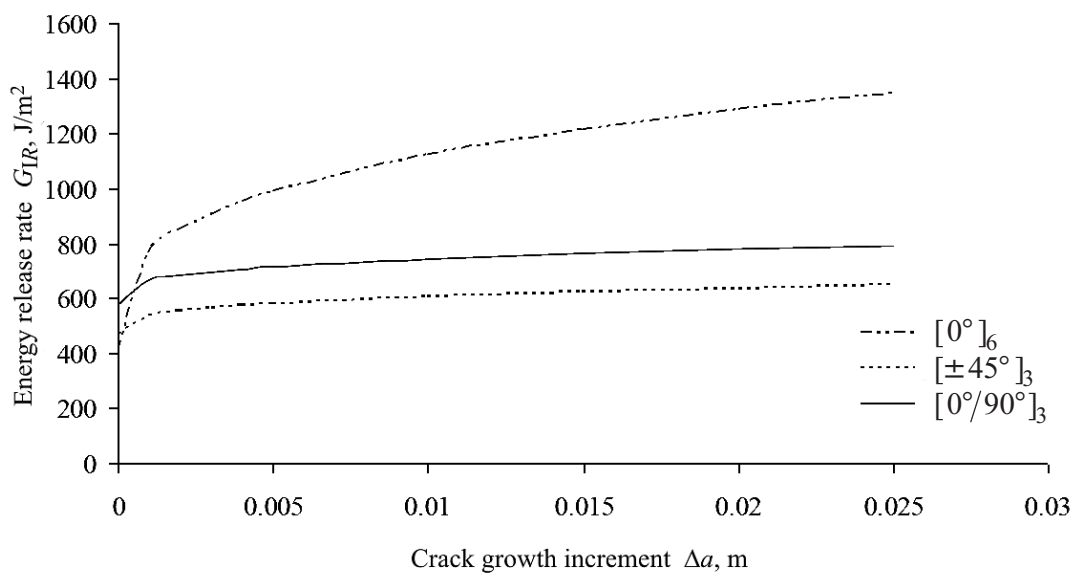

Fig. 6. Comparison of crack growth resistance curve of DCB specimens of different lay-ups made of glass/epoxy. 
as lay-up angle increases. Hundreds of literatures were published for different materials' systems to evaluate fracture energy. Closer agreements were obtained for materials, but exact values of $G_{\mathrm{I} c}$ or failure load are not observed. The reasons for the variation in results may be due to specimen geometry, lay-ups, fiber misalignment, fiber nesting, free edge effect, transverse matrix cracking, loading history and/or variation in material quality.

In the present study, the initiation toughness of glass/epoxy composite increases with increase in lay-up angle (Fig. 6) and is not true for steady state toughness. This may be due to the complex fracture behavior of composites. Since the lower bound of $G_{\text {Ic }}$ occurs in the absence of a fiber-bridged zone, one can conclude that $G_{\text {Ic }}$, increases as lay-up angle increases. However, since the initiation had occurred from a thin insert and not a truly sharp crack tip, the initiation value may not be valid in most of the cases [25].

Conclusions. The present study applies the crack growth resistance curve ( $R$-curve) method to predict the interface strength of composite specimens of three different lay-ups with artificially induced delamination. Based on linear elastic fracture mechanics approach, the $R$-curve method uses energy release rate as a fracture parameter to quantify the intensity of the energy state at the crack tip. From the experiments, it is verified that the $R$-curve method has the potential to be a practical engineering method for predicting the inter-laminar fracture strength of laminated glass/epoxy composites.

\section{Резиме}

Досліджується в'язкість руйнування і міжшарове руйнівне навантаження для зразків у вигляді двоконсольної балки зі скла/епоксидної смоли, що наносились трьома різними шарами. Для побудови кривої тріщиностійкості $(R$-крива) за допомогою представленої моделі необхідно знати історію прикладеного навантаження - переміщення та розповсюдження тріщини. На основі побудованої $R$-кривої визначено руйнівне навантаження на границі поділу шарів для зразків. Отримане значення руйнівного навантаження добре збігається $з$ експериментальним.

1. V. Kamala Kannan, S. Rajendra Boopathy, and B. Nageswara Rao, "Fracture strength of various lay-ups of carbon/epoxy laminates using the modified inherent flaw model," Eng. Fract. Mech., 75, 4834-4843 (2008).

2. A. Baker, S. Dutton, and D. Kelly, Composite Materials for Aircraft Structures, Second edition, AIAA Education Series, USA (2004).

3. M. F. S. F. de Moura, R. D. S. G. Campilho, A. M. Amaro, and P. N. B Reis, "Interlaminar and intralaminar fracture characterization of composites under mode I loading," Compos. Struct., 92, 144-149 (2010).

4. T. H. Walker, L. B. Ilcewicz, D. R. Polland, and C. C. Poe, Jr., "Tension fracture of laminates for transport fuselage. Pt. II: Large notches," in: Proc. of the Third NASA Advanced Composites Technology Conference, NASA CP-3178, Part 2 (1992), pp. 727-758. 
5. T. H. Walker, L. B. Ilcewicz, D. R. Polland, et al., "Tension fracture of laminates for transport fuselage. Pt. III: Structural configurations," in: Proc. of the Fourth NASA Advanced Composites Technology Conference, NASA CP-3229, Part 1 (1993), pp. 863-880.

6. M. M. Shokrieh, M. Heidari-Rarani, and M. R. Ayatollahi, "Delamination $R$-curve as material property of unidirectional glass/epoxy composites," Mater. Des., 34, 211-218 (2012).

7. Z. Suo, G. Bao, and B. Fan, "Delamination $R$-curve phenomena due to damage," J. Mech. Phys. Solids, 40, 1-16 (1992).

8. J. T. Wang, C. C. Poe, Jr., D. R. Ambur, and D. W. Sleight, "Residual strength prediction of damaged composite fuselage panel with $R$-curve method," Compos. Sci. Technol., 66, 2557-2565 (2006).

9. V. Tamuzs, S. Tarasovs, and U. Vilks, "Progressive delamination and fiber bridging modelling in double cantilever beam composite specimens," Eng. Fract. Mech., 68, 513-525 (2001).

10. B. Nageswara Rao and A. R. Acharya, "Evaluation of fracture energy $G_{\mathrm{I} c}$ using a double cantilever beam fibre composite specimen," Eng. Fract. Mech., 51, 317-322 (1995).

11. V. Alfred Franklin and T. Christopher, "Fracture energy estimation of DCB specimens made of glass/epoxy: an experimental study," Adv. Mater. Sci. Eng., Article ID 412601 (2013).

12. ASTM D5528-94a. Standard Test Method for Mode I Interlaminar Fracture Toughness of Unidirectional Continuous Fiber Reinforced Polymer Matrix Composites, Philadelphia, PA (1994), pp. 1-10.

13. C. C. Poe, Jr., C. E. Harris, T. W. Cotes, and T. H Walker, "Tension strength with discrete source damage," in: Proc. of the Fifth NASA Advanced Composites Technology Conference, NASA CP-3294, Vol. I, Part 1 (1994), pp. 369-437.

14. V. Q. Bui, E. Marechal, and H. Nguyen-Dang, "Imperfect interlaminar interfaces in laminated composites: delamination with the $R$-curve effect," Compos. Sci. Technol., 60, 2619-2630 (2000).

15. T. K. Jacobsen and B. F. Sorensen, "Mode I intra-laminar crack growth in composites - modelling of $R$-curves from measured bridging laws," Compos. Part A, 32, 1-11 (2001).

16. F. Ozdil and L. A. Carlsson, "Beam analysis of angle-ply laminate DCB specimens," Compos. Sci. Technol., 59, 305-315 (1999).

17. J. J. Polaha, B. D. Davidson, R. C. Hudson, and A. Pieracci, "Effects of mode ratio, ply orientation and precracking on the delamination toughness of a laminated composite," J. Reinf. Plast. Compos., 15, 141-173 (1996).

18. A. Laksimi, A. Ahmed Benyahia, M. L. Benzeggagh, and X. L. Gong, "Initiation and bifurcation mechanisms of cracks in multi-directional laminates," Compos. Sci. Technol., 60, 597-604 (2000).

19. N. S. Choi, A. J. Kinloch, and J. G. Williams, "Delamination fracture of multidirectional carbon-fibre/epoxy composites under mode I, mode II, and mixed-mode I/II loading," J. Compos. Mater., 33, 73-100 (1999). 
20. P. Robinson and D. Q. Song, "A modified DCB specimen for mode I testing of multidirectional laminates," J. Compos. Mater., 26, No. 11, 1554-1577 (1985).

21. R. L. Ramkumar and J. D Whitcomb, "Characterization of mode I and mixed mode delamination growth in T300/5208 graphite/epoxy," in: W. S. Johnson (Ed.), Delamination and Debonding of Materials, ASTM STP 876, Philadelphia (1985), pp. 315-335.

22. A. Laksimi, M. L. Benzeggagh, G. Jing, et al., "Mode I interlaminar fracture of symmetrical cross-ply composites," Compos. Sci. Technol., 41, 147-164 (1991).

23. A. B. de Morais, M. F. de Moura, A. T. Marques, and P. T. de Castro, "Mode-I interlaminar fracture of carbon/epoxy cross-ply composites," Compos. Sci. Technol., 62, 679-686 (2002).

24. T. K. O'Brien, "Generic aspects of fatigue of composite materials," J. Amer. Helicopter Soc., 32, No. 1, 13-18 (1987).

25. L.-Y. Xu and C.-H. Kou, "Effect of interfacial interleaf to the interlaminar fracture and intralaminar fracture of a new BMI matrix composite system," $J$. Reinf. Plast. Compos., 13, 509-540 (1994). 